\title{
ANALISIS DAMPAK PENERAPAN SISTEM SATU Terhadap KOMPENSASI FINANSIAL SUPIR ANGKUTAN KOTA Di KOTA BOGOR
}

\author{
Oleh: \\ Yasya Fuadi Hidayati ${ }^{1}$ \\ Lindawati Kartika ${ }^{2}$ \\ Hardiana Widyastuti ${ }^{3}$ \\ ${ }^{1,2,3)}$ Fakultas Ekonomi dan Manajemen Institut Pertanian Bogor \\ Email: \\ yasyafuadiehidayati@gmail.com
}

\begin{abstract}
The study aims to reduce congestion and the number of accidents in the area around the Bogor gardens. One of the impacts is that there is a change in the urban transport route with more distances. The urban transport route that has undergone the longest trajectory length changes used as the object of research. The purpose of this study is to analyze the perception of the city transport drivers, analyze the financial compensation of the city transport drivers before and after the SSA, to analyze the effect of SSA implementation on the compensation of transportation drivers. Source of data obtained through questionnaires, interviews and literature review. Data were analyzed by using descriptive analysis and multiple linear regression analysis. The results showed that city transport drivers did not agree with the implementation of SSA. Municipal transport driver income decreases 25-50 percent after the implementation of SSA. The results of multiple linear regression state that the variables that significantly influence the safety improvement variables.
\end{abstract}

Keywords: compensation, multiple regression analysis, SSA

\section{A. PENDAHULUAN}

Bogor merupakan kota dengan tingkat kepuasan berkendara terburuk di dunia, hal tersebut dibuktikan dari hasil survey indeks kepuasan berkendara dengan menggunakan aplikasi Waze (Putra, 2016). Indeks kepuasan berkendara ini mencantumkan enam indikator diantaranya kepadatan dan keparahan lalu lintas, keselamatan perjalanan, kualitas dan infrastruktur jalan, kemudahan akses 
ke SPBU dan parkir, analisa dampak sosial ekonomi, dan perasaan pengguna waze. Dari keenam indikator tersebut, Bogor mendapatkan penilaian indeks terendah kedua di dunia dari 38 negara yang disurvei oleh waze. Bogor mendapatkan nilai 2,15. Di atas Bogor hanya Kota Cebu di Filipina yang mendapat skor 1,15 sekaligus mendapatkan predikat kota terburuk untuk berkendara (Putra, 2016).

Pengelolaan sistem transportasi di Kota Bogor merupakan kendala yang sedang dihadapi pemerintah kota Bogor saat ini. Pertumbuhan transportasi setiap tahunnya mengalami peningkatan yang cukup tinggi, dengan pertumbuhan kendaraan rata-rata $(2013) \pm 17,72 \%$ antara lain mobil penumpang 64.705 unit (termasuk angkutan umum \pm 8.000 unit), sepeda motor 279.753 unit. Setiap tahun, rata-rata pertumbuhan terjadi hingga sepuluh persen, peningkatan tersebut terjadi cukup tinggi pada kendaraan pribadi dengan komposisi penggunaan kendaraan pribadi dan angkutan umum adalah 77\% : 33\% (DDLAJ Kota Bogor 2017).

Data pelayanan angkutan umum di wilayah Kota Bogor terdapat sebanyak 23 trayek angkutan kota dengan jumlah 3.412 kendaraan dan terdapat 10 trayek Angkutan Perkotaan AKDP dengan jumlah 4.644 kendaraan (DDLAJ Kota Bogor 2017). Jumlah transportasi angkutan kota yang cukup banyak dan jumlah transportasi yang semakin meningkat setiap tahunnya akan menambah beban transportasi yang cukup tinggi. Beban transportasi, bila tidak diimbangi dengan penyediaan prasarana yang memadai, akan menimbulkan permasalahan.

Permasalahan yang timbul akibat kepadatan kendaraan salah satunya yaitu kemacetan. Berbagai usaha untuk menanggulangi kemacetan lalu lintas yang dilakukan adalah dengan penambahan sarana jalan, pembangunan jalan tol, terowongan, sistem pengaturan lampu, sistem pengaturan jalan, perluasan lahan tanah. Namun, semua usaha tersebut memerlukan biaya dan waktu yang cukup tinggi (Ramanasari, Qomariyah, Purwanto, \& Yulipriyono, 2014). Salah satu bentuk pengelolaan lalu lintas yang dilakukan pemerintah kota Bogor dan Dinas Lalu Lintas Angkutan Jalan dengan biaya yang dikeluarkan cukup rendah dan tidak memerlukan waktu yang lama yaitu mengeluarkan kebijakann pemerintah, salah satunya dengan adanya penerapan sistem satu arah (SSA) bagi pengguna jalan dikota Bogor.

Penerapan Sistem Satu Arah tesebut memberikan banyak dampak terhadap pengguna jalan, baik pemilik kendaraan pribadi, pemilik kendaraan umum, maupun masyarakat sekitar. Salah satu dampak yang terjadi pada angkutan umum yaitu adanya perubahan trayek angkutan kota. Penerapan sistem satu arah ini telah merubah 13 trayek Angkutan kota dari 23 trayek angkutan kota di kota Bogor dengan tarif (ongkos) yang tidak berubah dari sebelum adanya penerapan sistem satu arah. Adapun perubahan trayek angkutan kota dan perubahan panjang lintasan trayek angkutan kota yang terdapat di kota Bogor dapat dilihat pada Gambar 1. 


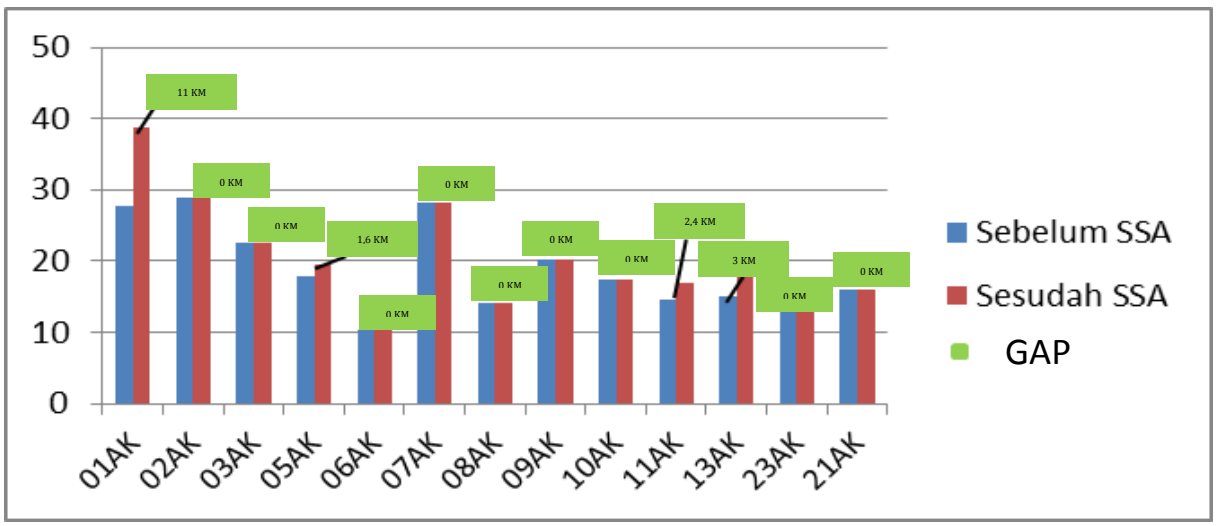

\section{Gambar 1}

\section{Perubahan Trayek dan Perubahan Panjang Lintasan Angkutan Kota}

Sumber : Dinas Lalu Lintas dan Angkutan Jalan Kota Bogor (2017)

Dari Gambar 1 dapat dilihat adanya penerapan Sistem satu arah ini telah merubah sebagian rute trayek angkutan kota di kota Bogor, khususnya angkutan kota yang melintasi kebun raya. Dari 13 trayek angkutan kota yang mengalami perubah, 4 trayek angkutan kota mengalami perubahan panjang lintasan yaitu, trayek angkutan kota 01 AK dengan perubahan jarak lintasan $11 \mathrm{KM}$ (PP), trayek angkutan kota 13AK dengan perubahan jarak lintasan $3 \mathrm{KM}$ (PP), trayek angkutan kota $11 \mathrm{AK}$ dengan perubahan jarak lintasan 2,4KM (PP), trayek angkutan kota 05AK dengan perubahan jarak lintasan 1,6 KM (PP). Dari Gambar 1 juga dapat dilihat perubahan jarak lintas dari 13 trayek angkutan kota yang mngalami perubahan jarak, trayek angkutan kota dengan perubahan paling jauh yaitu pada angkutan trayek 01AK, 13AK, $11 \mathrm{AK}$, dan $05 \mathrm{AK}$. Perubahan trayek lintasan pada angkutan tersebut, dua diantaranya akan dijadikan sebagai objek penelitian yaitu trayek angkutan 01AK dengan tarif Rp.5.000 dan 13 AK dengan tarif Rp. 3.500 .

\section{B. TINJAUAN PUSTAKA}

\section{Manajemen Lalu Lintas}

Mobilisasi penduduk yang semakin tinggi ini berimbas kepada meningkatnya jumlah kendaraan. Pertumbuhan kendaraan yang semakin tinggi, tidak diimbangi dengan pertumbuhan jalan yang ada. Sehingga hal ini menyebabkan terjadinya penumpukan suatu kendaraan disuatu ruas jalan tertentu dan menibulkan kemacetan.

(Kasikoen \& Atmaja, 2012) menjelaskan bahwa kemacetan lalu lintas adalah situasi tersendatnya atau bahkan terhentinya lalu lintas yang disebabkan oleh banyaknya kendaraan melebihi kapasitas jalan. Kemacetan lalu lintas banyak terjadi di kotakota besar, utamanya yang tidak mempunyai transportasi umum yang baik atau memadai, juga tidak seimbangnya antara ketersediaan jalan dengan jumlah kendaraan.

Untuk mengatasi hal tersebut, perlu adanya manajemen dan rekayasa lalu lintas sebagaimana yang jeaskan oleh Ramanasari (Ramanasari, Qomariyah, Purwanto, \& Yulipriyono, 2014) bahwa manajemen dan rekayasa lalu lintas yang 
dinamis diantaranya adalah penambahan ruas jalan atau manajemen pengaturan arus. Melihat dari banyak sisi, penambahan ruas jalan menjadi solusi yang kurang efektif dan efisien dikarenakan keterbatasan lahan serta besarnya biaya yang harus dikeluarkan. Dengan demikian, manajemen pengaturan arus bisa menjadi solusi efektif dan efisien karena teknis yang dilakukan hanya penataan dan pengaturan ruas jalan serta simpang yang berpotensi menimbulkan kemacetan. Bentuk manajemen pengaturan arus yang dapat diterapkan adalah manajemen lalu lintas sistem satu arah.

Ramanasari (Ramanasari, Qomariyah, Purwanto, \& Yulipriyono, 2014), manajemen lalu lintas satu arah adalah suatu pola lalu lintas dengan merubah jalan dua arah menjadi jalan satu arah yang berfungsi untuk meningkatkan kapasitas jalan dan persimpangan. Sistem ini biasa diterapkan di wilayah perkotaan guna meningkatkan keselamatan dan kelancaran lalu lintas. Kelebihan sistem satu arah, diantaranya:

1. Mengurangi jumlah konflik di persimpangan serta memudahka pengaturan koordinasi sinyal lampu lalu lintas.

2. Mengurangi kecelakaan lalu lintas, walaupun demikian fasilitas menjadi bertambah mengingat kecepatan kendaraan meningkat.

3. Meningkatan kecepatan rata-rata kendaraan pada sistem jaringan jalan, walaupun demikian tidak berarti mempercepat waktu perjalanan.

4. Memungkinkan terjadinya peningkatan ekonomi/pendapatan wilayah, yang semulanya adalah kawasan yang tenang menjadi ramai.

Kekurangan sistem satu arah, diantaranya:

1. Dapat menyebabkan waktu perjalanan menjadi lebih lama karena harus berputar.

2. Memungkinkan fasilitas bertambah akibat kecepatan kendaraan menjadi lebih tinggi.

3. Menyulitkan penyeberang jalan apabila tidak diberikan tempat penyeberangan khusus.

4. Menyulitkan angkutan umum apabila tidak disediakan lajur khusus yang berlawanan arus.

5. Menyulitkan masyarakat yang tidak terbiasa berpergian ke daerah tersebut karena rute menjadi berputar-putar.

Adapun contoh penerapan sistem satu arah di Kota Semarang memiliki tujuan, Ramanasari (Ramanasari, Qomariyah, Purwanto, \& Yulipriyono, 2014) yaitu:

1. Melakukan persebaran lalu lintas berbasis pemerataan sehingga pada jalanjalan kota yang awalnya sepi dapat menjadi ramai dan yang awalnya ramai menjadi berkurang tingkat keramaiannya

2. Menghasilkan kondisi lalu lintas yang tertib, lancar, aman, nyaman dan efisien karena berkurangnya waktu tundaan pada simpang sehingga antrian menjadi berkurang

3. Memberikan masukan kepada Pemerintah Kota Semarang mengenai penataan sistem transportasi kota. 
Keputusan Walikota Bogor Nomor 551.45-63 Tahun 2016 tentang Tim Pelaksana Penerapan Sistem Satu Arah di Seputar Kebun Raya Bogor. Penerapan sistem satu arah dikota Bogor bertujuan untuk mengurangi tingkat kemacetan yang ada dikota Bogor, khususnya di daerah sekitar kebun raya. DLLAJ (2017), adapun tujuan diterapkannya sistem satu arah yaitu:

1. Peningkatan kecepatan lalu lintas

2. Peningkatan waktu tempuh (penghematan waktu)

3. Peningkatan keselamatan pengguna jalan (pengendara dan pejalan kaki).

\section{Kompensasi}

Kompensasi merupakan sesuatu yang diterima karyawan sebagai balas jasa terhadap hasil kerja karyawan (Mondy \& Martocchio, 2008). Kompensasi adalah total seluruh imbalan yang diterima para karyawan sebagai pengganti jasa yang telah mereka berikan. Tujuan umum pemberian kompensasi adalah untuk menarik, mempertahankan dan memotivasi karyawan.

(Kartika, Jayawinangun, \& Mangkuprawira, 2016), kompensasi dapat didefinisikan sebagai segala sesuatu yang diterima karyawan baik kompensasi finansial dan kompensasi non-finansial sebagai balas jasa terhadap hasil kerja karyawan.

(Mondy \& Martocchio, 2008) menjelaskan bahwa kompensasi terdiri dari dua jenis yaitu kompensasi finansial dan kompensasi non-finansial. Kompensasi finansial terdiri dari bayaran yang diterima seseorang dalam bentuk langsung dan tidak langsung. Adapun jenisnya, yaitu:

1. Langsung (gaji, upah, bonus dan komisi)

2. Tidak langsung (program asuransi, bantuan sosial untuk karyawan, tunjangan, ketidakhadiran yang dibayar).

Kompensasi Non-finansial yaitu kepuasan yang diterima seseorang dari pekerjaan itu sendiri atau dari lingkungan psikologis atau fisik tempat orang tersebut bekerja.

\section{Manajemen Lalu Lintas dan Kompensasi}

Permasalahan lalu lintas di Kota Bogor sedang mendapat perhatian khusus dari pemerintah kota Bogor. Pertumbuhan jumlah kendaraan setiap tahunnya merupakan salah satu faktor permasalahan lalu lintas dan menimbulkan kemacetan dikota Bogor. Salah satu upaya Pemerintah kota Bogor untuk mengurangi masalah lalu lintas tersebut yaitu dengan mengeluarkan kebijakan berupa penerapan sistem satu arah (SSA). Penerapan sistem satu arah ini merupakan salah satu langkah Pemerintah kota Bogor untuk mengurangi kemacetan, juga sekaligus pembenahan sistem transportasi di Kota Bogor. Uji coba kebijakan ini diterapkan dengan adanya koordinasi dan bantuan dengan Dinas Lalu Lintas dan Angkutan Jalan Kota Bogor. Penerapan sistem satu arah ini bertujuan untuk mengurangi tingkat kemacetan yang ada dikota Bogor, khususnya di daerah sekitar kebun raya. Adapun tujuan diterapkannya sistem satu arah yaitu : Peningkatan kecepatan lalu lintas, peningkatan waktu tempuh (penghematan waktu), peningkatan keselamatan pengguna jalan (pengendara dan pejalan kaki). 
penerapan sistm satu arah ini berdampak salah satunya pada supir angkutan kota yang mengalami perubahan panjang lintasan trayek menjadi lebih panjang dari sebelumnya. Penelitian ini bertujuan untuk mengetahui adanya perbedaan kompensasi (pendapatan) terhadap supir angkutan Bogor khususnya pada trayek angkutan 01 AK dan 13AK yang mengalami perubahan lintasan trayek paling panjang dari trayek angkutan lainnya. Dimana kompensasi merupakan balas jasa (imbalan) yang didapatkan oleh supir angkutan kota tersebut. Hasil dari penelitian ini dapat dirumuskan sebagai implikasi manajerial dan diharapkan dapat menjadi pertimbangan dan digunakan sebagai acuan bagi pemerintah kota Bogor agar memperhatikan supir angkutan kota Bogor kedepannya. Kerangka pemikiran dapat dilihat pada Gambar 2.

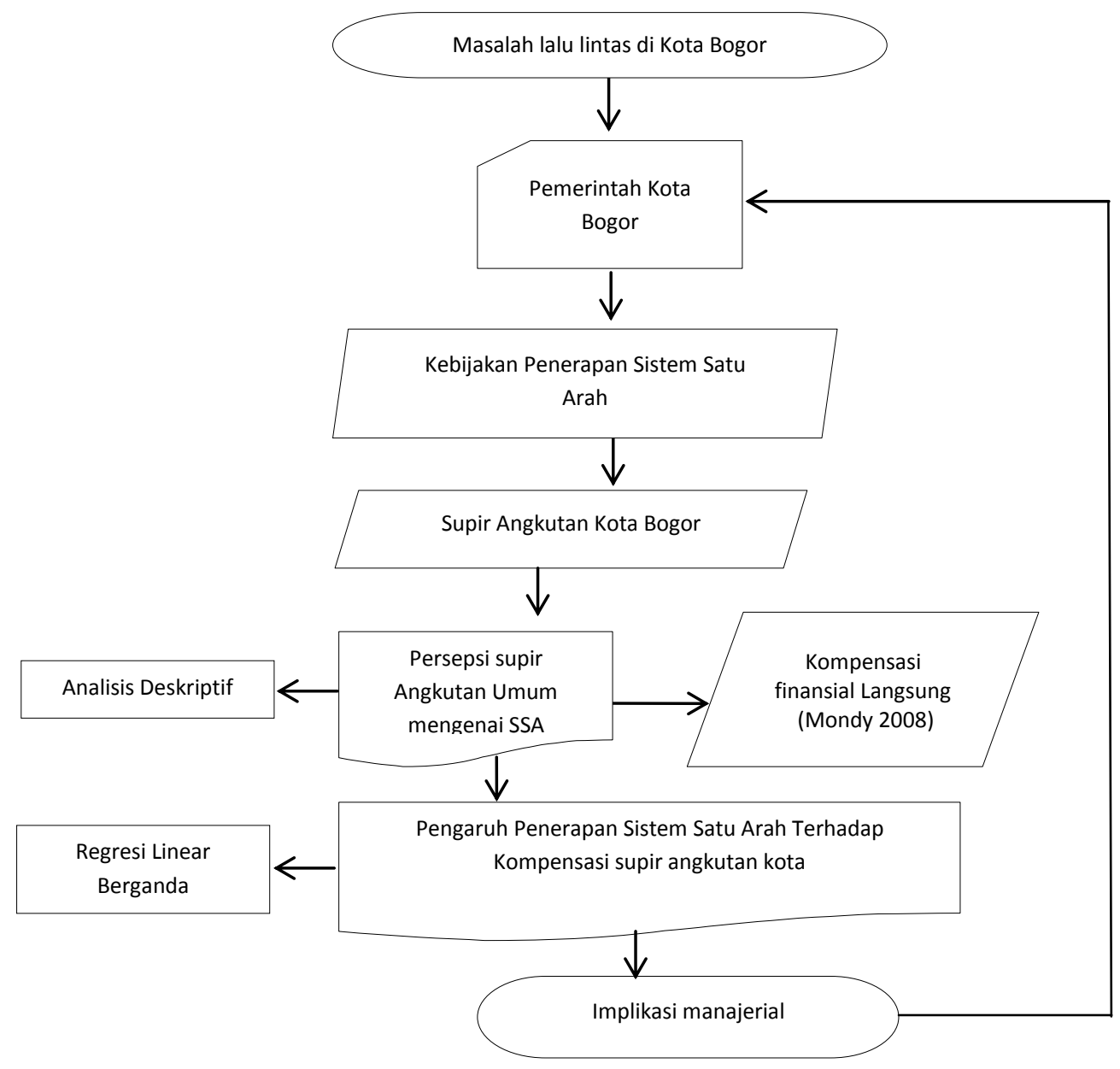

Gambar 2. Rerangka Konseptual

\section{Pengembangan Hipotesis}

Siregar (2013), hipotesis berasal dari bahasa Yunani yang mempunyai dua kata "hupo" (sementara) dan "thesis" (pernyataan atau teori). Hipotesis adalah pernyataan sementara yang masih lemah keberadaannya, maka perlu diuji kebenarannya. Maka hipotesis yang diusulkan adalah secara simultan dan parsial, yaitu: 
Hipotesis secara simultan (bersama-sama):

$\mathrm{H}_{0}=$ Komponen Sistem Satu Arah (Peningkatan kecepatan lalu lintas, Peningkatan waktu tempuh, Peningkatan keselamatan pengguna jalan) secara bersama-sama tidak berpengaruh signifikan terhadap kompensasi supir angkutan kota Bogor

$\mathrm{H}_{1}=$ Komponen Sistem Satu Arah (Peningkatan kecepatan lalu lintas, Peningkatan waktu tempuh, Peningkatan keselamatan pengguna jalan) secara bersama-sama berpengaruh signifikan terhadap kompensasi supir angkutan kota Bogor

Hipotesis secara parsial (Individu):

$$
\begin{aligned}
& \mathbf{X}_{1} \rightarrow \mathbf{Y} \\
& \mathrm{H}_{0}=\text { Peningkatan kecepatan lalu lintas secara parsial tidak berpengaruh } \\
& \text { terhadap kompensasi supir angkutan kota Bogor } \\
& \mathrm{H}_{\mathrm{a} / 1}=\text { Peningkatan kecepatan lalu lintas secara parsial berpengaruh } \\
& \text { terhadap kompensasii supir angkutan kota Bogor } \\
& \mathbf{X}_{2} \quad \rightarrow \quad \mathbf{Y} \\
& \mathrm{H}_{0}=\text { Peningkatan waktu tempuh secara parsial tidak berpengaruh } \\
& \text { terhadap kompensasi supir angkutan kota Bogor. } \\
& \mathrm{H}_{\mathrm{a} / 2}=\text { Peningkatan waktu tempuh secara parsial berpengaruh terhadap } \\
& \text { kompensasi supir angkutan kota Bogor } \\
& \mathbf{X}_{\mathbf{3}} \quad \rightarrow \quad \mathbf{Y}
\end{aligned}
$$

\section{METODE PENELITIAN}

Jenis data yang digunakan pada penelitian ini yaitu data kuantitatif dan kualitatif, data kuantitatif yang digunakan yaitu berupa hasil dari pemberian kuesioner dengan menggunakan skala pengukuran data interval. Data kualitatif digunakan untuk mendeskripsikan secara jelas hasil wawancara secara langsung kepada responden berupa memberikan pertanyaan langsung kepada responden. Sumber data yang digunakan pada penelitian ini terdiri dari data primer dan data sekunder. Data primer pada penelitian ini dapat dilakukan dengan wawancara langsung kepada supir angkutan kota khususnya trayek 01AK dan 13AK di Kota Bogor. Selain dengan wawancara, supir angkutan kota diberikan kuesioner. Selain dari supir angkutan kota di kota Bogor, data primer juga didapatkan dari wawancara langsung kepada DLLAJ kota Bogor.

Sampel yang telah ditentukan dengan menggunakan rumus slovin yaitu berjumlah sebanyak 68 responden. peneliti membagi kedalam 2 (dua) objek supir angkutan kota. Jumlah sampel yang akan digunakan sebagai penelitian berjumlah 
68 orang, dengan pembagian masing-masing 19 orang pada trayek angkutan kota 01 AK dan 49 orang pada trayek angkutan kota 13 AK. Kuesioner yang telah disebar selanjutnya dilakukan uji kualitas data yaitu berupa uji validitas dan reabilitas. Uji validitas dikatakan valid jika $r_{\text {hitung }}>$ dari $r_{\text {tabel }}$. Hasil uji validitas instrumen dapat dilihat pada Tabel 1.

Tabel 1 Hasil Uji Validitas Instrumen

\begin{tabular}{lcccc}
\hline \multicolumn{1}{c}{ Variabel } & $\begin{array}{c}\text { No } \\
\text { Instrumen }\end{array}$ & $\mathbf{r}_{\text {tabel }}$ & $\mathbf{r}_{\text {hitung }}$ & Ket \\
\hline \multirow{2}{*}{ Peningkatan kecepatan lalu lintas $\left(\mathrm{X}_{1}\right)$} & 1 & 0,463 & 0,615 & Valid \\
& 2 & 0,463 & 0,635 & Valid \\
& 3 & 0,463 & 0,726 & Valid \\
\hline \multirow{2}{*}{ Peningkatan waktu tempuh $\left(\mathrm{X}_{2}\right)$} & 1 & 0,463 & 0,547 & Valid \\
& 2 & 0,463 & 0,521 & Valid \\
& 3 & 0,463 & 0,498 & Valid \\
Peningkatan keselamatan pengguna jalan (pengendara) & 4 & 0,463 & 0,724 & Valid \\
$\left.\mathrm{X}_{3}\right)$ & 1 & 0,463 & 0,722 & Valid \\
& 2 & 0,463 & 0,621 & Valid \\
\hline \multirow{2}{*}{ Kompensasi Finansial $(Y)$} & 1 & 0,463 & 0,493 & Valid \\
& 2 & 0,463 & 0,543 & Valid \\
& 3 & 0,463 & 0,492 & Valid \\
\hline
\end{tabular}

Berdasarkan Tabel 1 nilai $\mathrm{r}_{\text {hitung }}>$ dari $\mathrm{r}_{\text {tabel }}$, dengan demikian dapat disimpulkan bahwa seluruh butir pernyataan dinyatakan valid. Uji yang dilakukan selanjutnya, adalah uji reliabilitas. Menurut (Siregar, 2013) reliabilitas dilakukan untuk mengetahui seberapa jauh hasil pengukuran tetap konsisten apabila dilakukan pengukuran dua kali atau lebih terhadap gejala yang sama dengan menggunakan alat pengukur sama. Uji reabilitas dalam penelitian ini menggunakan teknik Alpha Cronbach dan dapat dikatakan reliable jika nilai Alpha $(\alpha)>0,6$. Hasil Uji reabilitas dapat dilihat pada Tabel 2.

Tabel 2 Hasil Uji Reliabilitas

\begin{tabular}{lcc}
\hline \multicolumn{1}{c}{ Variabel } & Cronbach's Alpha & N of Items \\
\hline Peningkatan kecepatan lalu lintas $\left(\mathrm{X}_{1}\right)$ & 0,734 & 3 \\
Peningkatan waktu tempuh $\left(\mathrm{X}_{2}\right)$ & 0,739 & 4 \\
Peningkatan keselamatan pengguna jalan (pengendara) $\left(\mathrm{X}_{3}\right)$ & 0,724 & 2 \\
Kompensasi Finansial $(\mathrm{Y})$ & 0,685 & 4 \\
\hline
\end{tabular}

Berdasarkan Tabel 2 Cronbach's Alpha yang didapat > dari 0,6, dengan demikian keempat variabel tersebut dapat dikatakan reliable.

\section{HASIL DAN PEMBAHASAN}

\section{Karakteristik Responden}

Berdasarkan hasil karakteristik responden dapat dilihat Perubahan yang dialami cukup tinggi, responden yang mengeluarkan bahan bakar sebelum adanya penerapan (SSA) sebanyak 23,5 liter setiap harinya, sedangkan setelah adanya penerapan (SSA) bahan bakar yang dikeluarkan setiap harinya sebanyak 25 liter 
dengan peningkatan peerubahan yang terjadi sebesar 1,5 liter. Hal tersebut dapat terjadi karena perubahan jarak lintasan angkutan umum. Perubahan jarak lintas juga berpengaruh terhadap RTT supir angkutan kota setiap harinya, jumlah RTT supir angkutan kota yang didapat sebelum adanya penerapan (SSA) mencapai 12 RTT/hari, sedangkan setelah adanya penerapan (SSA) hanya mencapai 11 RTT/hari dengan perubahan penurunan sebesar 1 RTT. Selain itu, jumlah penumpang angkutan kota pun menurun dari biasanya. Jumlah penumpang ratarata sebelum adanya penerapan (SSA) bisa didapatkan setiap RTT nya berjumlah 16 orang, sedangkan setelah adanya penerapan (SSA) jumlah penumpang hanya bisa didapatkan setiap RTT nya berjumlah 14 orang dengan perubahan penurunan pendaptan penumpang sebesar 2. Setoran yang diberikan kepada pemilik angkutan kota tidak berubah dari sebelum dan sesudah adanya SSA yaitu sebesar Rp.150.000. Dari 68 resonden 2 diantaranya merupakan pemilik angkutan kota tersebut sehingga mereka tidak memberikan setoran kepada pemilik angkutan kota. Faktor- Faktor tersebut tentunya berdampak terhadap pendapatan yang didapat supir angkutan kota tersebut. Biasanya mereka bisa mendapatkan uang dengan jumlah rata-rata sebesar Rp. 210.000, sedangkan setelah adanya penerapan sistem satu arah pendapatan supir angkutan kota menurun yaitu sebesar Rp. 190.000. Jika dipresentasekan pendapatan supir angkutan kota tersebut berkurang 25-50\% setelah adanya penerapan SSA tersebut

\section{Hasil Analisis Deskriptif Persepsi Supir Angkutan Kota mengenai Dampak Penerapan Sistem Satu Arah (SSA)}

Analisis deskriptif yang dapat dijadikan kesimpulan berdasarkan data yang memiliki frekuensi sering muncul, atau yang disebut dengan modus. Hasil persepsi supir angkutan kota terhadap dampak penerapan sistem satu arah dapat dilihat pada Tabel 3 .

Tabel 3

Persepsi Supir Angkutan Kota terhadap Dampak Penerapan Sistem Satu Arah

\begin{tabular}{|c|c|c|c|c|c|c|c|c|}
\hline \multirow[b]{2}{*}{ No } & \multirow[b]{2}{*}{ Variabel } & \multicolumn{5}{|c|}{ Jawaban Responden } & \multirow[b]{2}{*}{ Modus } & \multirow[b]{2}{*}{ Ket } \\
\hline & & $\begin{array}{c}1 \\
\text { STS }^{\mathrm{a}} \\
(\%) \\
\end{array}$ & $\begin{array}{c}2 \\
\mathrm{TS}^{\mathrm{b}} \\
(\%)\end{array}$ & $\begin{array}{c}3 \\
\mathrm{KS}^{\mathrm{c}} \\
(\%) \\
\end{array}$ & $\begin{array}{c}4 \\
\mathrm{~S}^{\mathrm{d}} \\
(\%) \\
\end{array}$ & $\begin{array}{c}5 \\
\mathrm{SS}^{\mathrm{e}} \\
(\%)\end{array}$ & & \\
\hline 1 & $\mathrm{X}_{1}$ & 3,4 & 32,4 & 37,7 & 12,7 & 13,7 & $73,5 \%(1,2,3)$ & Tidak setuju \\
\hline 2 & $\mathrm{X}_{2}$ & 16,7 & 56,4 & 49,5 & 9,3 & 1,5 & $122,6 \%(1,2,3)$ & Tidak setuju \\
\hline 3 & $\mathrm{X}_{3}$ & 2,9 & 11,8 & 35,3 & 35 & 16,9 & $51,9 \%(4,5)$ & Setuju \\
\hline
\end{tabular}

Berdasarkan Tabel 3, diperoleh hasil dari banyaknya modus setiap pertanyaan pada masing-masing variabel. Nilai modus terbanyak pada setiap variabel berbeda. Pada variabel pertama yaitu Peningkatan kecepatan lalu lintas nilai modus terbanyak adalah 1,2,3 atau termasuk dalam kriteria tidak setuju. Hasil tersebut menunjukan bahwa supir angkot tidak setuju dengan adanya penerapan sistem satu arah jarak trayek yang ditempuh semakin mudah, bahkan 
supir angkot berpendapat jarak trayek setelah adanya penerapan sistem satu arah semakin jauh dari jarak trayek sebelumnya. Pada variabel kedua yaitu peningkatan waktu tempuh nilai modus terbanyak adalah 1, 2, 3 atau termasuk dalam kriteria tidak setuju. Hasil tersebut menunjukan bahwa supir angkot tidak setuju dengan adanya penerapan sistem satu arah dapat menghilangkan kemacetan. Kemacetan masih terjadi dibeberapa titik sekitar kebun raya, tetapi kemacetan berkurang (tidak hilang sepenuhnya). Dan pada variabel ketiga yaitu Peningkatan keselamatan pengguna jalan (pengendara) nilai modus terbanyak adalah 4,5 atau termasuk dalam kriteria setuju. Hasil tersebut menunjukan bahwa supir angkot sangat setuju dengan adanya penerapan sistem satu arah berdampak pada peningkatan keselamatan mereka, selain mereka jadi lebih tertib dalam berkendara, jalanan yang dilalui pun hanya satu jalur (tidak berlawanan arah).

\section{Pengaruh Penerapan Sistem Satu Arah terhadap Kompensasi Finansial Supir Angkutan Kota di Kota Bogor dengan Analisis Regresi}

\section{Hasil Uji Koefisien Determinasi $\left(\mathbf{R}^{2}\right)$}

Uji Koefisien Determinasi $\left(\mathrm{R}^{2}\right)$ dilakukan untuk mengetahui seberapa besar dampak penerapan sistem satu arah terhadap kompensasi finansial yang didapatkan supir angkutan kota di kota Bogor. Nilai $R$ Square yang diperoleh dari hasil pengolahan data adalah sebesar 0.74 atau $7.4 \%$. Hal ini menunjukkan bahwa penerapan sistem satu arah terhadap kompensasi finansial supir angkutan kota dikota Bogor hanya memberikan dampak 7.4\%. Sedangkan sisanya sebesar 92.6\% berdampak kepada hal lain yang tidak diteliti dalam penelitian ini.

\section{Hasil Uji F}

Uji $F$ digunakan untuk mengevaluasi apakah variabel independen berpengaruh secara simultan terhadap variabel independen. Taraf signifikasi $(\alpha)$ yang digunakan pada uji $\mathrm{F}$ ini sebesar $5 \%$, dan $\mathrm{F}_{\text {tabel }}$ sebesar 2.70. Hasil uji $\mathrm{F}$ dari pengolahan regresi dapat dilihat pada tabel ANOVA melalui kolom $\mathrm{F}_{\text {hitung }}$ atau kolom signifikansi (sig.). Hasil Uji f diperoleh nilai $\mathrm{F}_{\text {hitung }}$ sebesar 2.791 dengan nilai signifikansi 0.047 . Hasil tersebut menunjukan bahwa nilai $\mathrm{F}_{\text {hitung }}$ lebih besar dari nilat $\mathrm{F}_{\text {tabel }}(2.791>2.70)$ dan tingkat signifikansi dibawah 0.05 yaitu 0.047 , sehingga $\mathrm{H} 0$ ditolak dan $\mathrm{H} 1$ diterima. Dari hasil tersebut dapat disimpulkan bahwa Komponen Sistem Satu Arah sebagai variabel independen yaitu Peningkatan kecepatan lalu lintas, Peningkatan waktu tempuh, Peningkatan keselamatan pengguna jalan berpengaruh secara bersama-sama (simultan) berpengaruh signifikan terhadap kompensasi supir angkutan kota Bogor.

\section{Hasil Uji-t}

Uji-t digunakan untuk membuktikan apakah variabel independen secara individu mempengaruhi variabel dependen. Taraf signifikasi $(\alpha)$ yang digunakan pada uji-t ini sebesar 5\% (0.05) dan $\mathrm{t}_{\text {tabel }}$ sebesar 1.998. Berdasarkan Hasil Uji-t , interpretasi secara signifikan pada masing-masing variabel independen dapat dilakukan sebagai berikut: 
1. Peningkatan kecepatan lalu lintas $\left(\mathrm{X}_{1}\right)$

Berdasarkan hasil $t_{\text {hitung }}$ untuk Peningkatan kecepatan lalu lintas (kecepatan) 0.379 dengan nilai signifikansi 0.706 . Hasil tersebut menunjukan bahwa nilai $\mathrm{t}_{\text {hitung }}$ lebih kecil dari nilat $\mathrm{t}_{\text {tabel }}(0.379<1.998)$ dan tingkat signifikansi diatas 0.05 yaitu 0.706 , sehingga $\mathrm{H}_{0}$ diterima dan $\mathrm{H}_{1}$ ditolak. Dari hasil tersebut dapat disimpulkan Peningkatan kecepatan lalu lintas secara parsial tidak berpengaruh terhadap kompensasi supir angkutan kota Bogor atau dengan kata lain Peningkatan kecepatan lalu lintas (kecepatan) memiliki pengaruh yang kecil. Hal tersebut dikarenakan jarak tempuh yang dilalui lebih panjang dari jarak tempuh sebelumnya tetapi dengan tarif angkutan yang sama, yang menyebabkan pendapatan (kompensasi) supir angkutan menurun.

\section{Peningkatan waktu tempuh/penghematan waktu $\left(\mathrm{X}_{2}\right)$}

Hasil $t_{\text {hitung }}$ untuk peningkatan waktu tempuh (waktu tempuh) 0.707 dengan nilai signifikansi 0.482 . Hasil tersebut menunjukan bahwa nilai $\mathrm{T}_{\text {hitung }}$ lebih kecil dari nilat $\mathrm{t}_{\text {tabel }}(0.707<1.998)$ dan tingkat signifikansi diatas 0.05 yaitu 0.482 , sehingga $\mathrm{H}_{0}$ diterima dan $\mathrm{H}_{1}$ ditolak. Dari hasil tersebut dapat disimpulkan peningkatan waktu tempuh secara parsial tidak berpengaruh terhadap kompensasi supir angkutan kota Bogor atau dengan kata lain Peningkatan waktu tempuh (waktu tempuh) memiliki pengaruh yang kecil. Hal tersebut dikarenakan banyaknya keluhan penumpang kepada supir angkutan kota karena jarak yang ditempuh menjadi jauh, sehingga supir sulit mendapatkan penumpang dan bahan bakar yang dikeluarkan lebih banyak dari sebelumnya, yang menyebabkan pendapatan (kompensasi) supir angkutan menurun.

\section{Peningkatan keselamatan pengguna jalan (pengendara dan pejalan kaki) $\mathrm{X}_{3}$}

Hasil $t_{\text {hitung }}$ untuk peningkatan keselamatan pengguna jalan (keselamatan) 2.015 dengan nilai signifikansi 0.048. Hasil tersebut menunjukan bahwa nilai $\mathrm{t}_{\text {hitung }}$ lebih besar dari nilat $\mathrm{t}_{\text {tabel }}(2.015>1.998)$ dan tingkat signifikansi dibawah 0.05 yaitu 0.048 , sehingga $\mathrm{H}_{0}$ ditolak dan $\mathrm{H}_{1}$ diterima. Dari hasil tersebut dapat disimpulkan bahwa Peningkatan keselamatan pengguna jalan secara parsial berpengaruh terhadap kompensasi supir angkutan kota Bogor. Hal tersebut menunjukan bahwa variabel keselamatan menciptakan nilai yang positif untuk kompensasi supir angkutan kota, jika supir angkutan kota berkendara dengan hatihati dan memberikan kenyamanan untuk penumpangnya, maka penumpang akan terus menggunakan jasa angkutan kota sehingga akan berdampak positif terhadap pendapatan supir angkutan kota itu sendiri. Sebaliknya penumpang akan merasa tidak nyaman dan tidak mau untuk menggunakan jasa angkutan umum dan akan memberikan dampak negatif terhadap pendapatan supir angkutan itu sendiri.

Berdasarkan dari hasil uji t secara keseluruhan dari 3 variabel, variabel yang berpengaruh secara signifikan yaitu variabel Peningkatan keselamatan pengguna jalan (pengendara dan pejalan kaki) $X_{3}$. Jika dimasukan kedalam persamaan regresi linear berganda dapat dituliskan kedalam bentuk persamaan sebagai berikut:

$$
\mathrm{Y}=4.752+0.062 \mathrm{X}_{1}+0.084 \mathrm{X}_{2}+\mathbf{0 . 3 5 7 \mathbf { X } _ { 3 }}
$$


Keterangan:

$\mathrm{Y}=$ Kompensasi

$\mathrm{X}_{1}=$ Peningkatan kecepatan lalu lintas

$\mathrm{X}_{2}=$ Peningkatan waktu tempuh

$\mathrm{X}_{3}=$ Peningkatan keselamatan pengguna jalan

Berdasarkan hasil persamaan regresi linear berganda tersebut, dapat disimpulkan bahwa Peningkatan keselamatan pengguna jalan (keselamatan) mendapatkan hasil sebesar 0.357 , yang berarti nilai $\mathrm{X}_{3}$ adalah 0.357 bertanda positif menyatakan bahwa apabila Peningkatan keselamatan pengguna jalan (keselamatan) ditingkatkan setiap satuan nilai, maka akan meningkatkan kompensasi finansial supir angkutan kota sebesar 0.357 dan diasumsikan untuk peubah lain 0. Dari hasil tersebut juga, dapat disimpulkan bahwa Peningkatan keselamatan pengguna jalan secara parsial berpengaruh terhadap kompensasi supir angkutan kota Bogor.

\section{Pertanyaan Terbuka Mengenai Penerapan Sistem Satu Arah}

Peneliti membuat pertanyaan terbuka pada kuesioner untuk mendapatkan jawaban responden yang lebih mendalam. Pertanyaan terbuka terdiri dari satu butir pertanyaan berupa tanggapan atau opini supir angkutan kota trayek angkutan 01AK dan $13 \mathrm{AK}$ agar sistem satu arah yang sudah berjalan menjadi lebih baik. Berdasarkan pertanyaan terbuka mengenai penerapan sistem satu arah agar menjadi lebih baik terdapat beberapa opini, diantaranya adanya pembuatan halte penumpang, pembuatan halte penumpang dimaksudkan agar angkutan kota itu sendiri mendapatkan tempat berhenti untuk penumpang yang akan naik dan turun, karena setelah adanya penerapan SSA ini menaikan atau menurunkan penumpang dirasakan agak sulit dari biasanya. Pembuatan halte untuk penumpang ini juga dapat memberikan rasa aman yang lebih bagi penumpang sehingga terciptanya keselamatan antar pengguna jalan tersebut. Opini selanjutnya yaitu dengan adanya pembuatan pelican crossing, pelican crossing adalah penyeberangan pejalan kaki yang dikontrol lampu lalu lintas dan dioperasikan oleh pejalan kaki. Dimana pejalan kaki harus menekan tombol untuk meminta "waktu hijau" pada pengendara kendaraan sehingga pengendara kendaraan berhenti dan pejalan kaki dapat menyebrangi jalan. Pelican crossing berfungsi untuk memudahkan pengguna jalan menyebrang jalan dan disarankan pembuatan pelican crossing ini berada tidak jauh dari halte yang dibuat. Opini selanjutnya yaitu adanya penyesuaian tarif angkutan dengan jarak yang baru agar pendapatan supir angkutan kota tersebut tidak mengalami penurunan dan kebutuhan sandang dan pangan mereka bisa terpenuhi dengan baik. Namun, sebagian supir angkutan kota juga memberikan opini jika sebaiknya pemerintah Kota Bogor mengembalikan kebijakan mereka kepada kebijakan awal, yaitu jalanan dua arah. Hal tersebut dirasakan karena jalanan dua arah lebih memudahkan dalam jarak trayek, memudahkan mendapatkan penumpang dan pengeluaran bahan bakar tidak sebanyak setelah adanya penerapan SSA. 


\section{E. SIMPULAN}

Berdasarkan hasil penelitian yang telah dilakukan, maka dapat diketahui:

1. Supir angkutan kota khususnya trayek 01 AK dan 13 AK kurang setuju dengan adanya penerapan ssa dikota Bogor, hal tersebut dikarenakan penerapan SSA berakibat kurang baik bagi mereka, diantaranta trayek angkutan menjadi jauh, sulit untuk mendapatkan penumpang karena tidak adanya pemberhentian khusus untuk angkot itu sendiri

2. Pendapatan supir angkot tersebut menjadi lebih sedikit (berkurang) dari sebelumnya dengan presentase $25-50 \%$ setelah adanya penerapan SSA tersebut, hal itu dikarenakan biaya bahan bakar yang dikeluarkan bertambah lebih banyak karena trayek angkutannya semakin jauh, RTT yang di dapat setiap harinya pun berkurang, tetapi dengan tarif angkutan yang sama (tidak ada kenaikan) dari tarif sebelum adanya SSA. Selain hal tersebut, volume penumpang juga berkurang dikarenakan banyaknya angkutan umum yang melewati jalur serupa (peningkatan saingan).

3. Dari hasil perhitungan regresi linear berganda menyatakan bahwa variabel yang berpengaruh secara signifikan yaitu variabel Peningkatan keselamatan pengguna jalan (pengendara dan pejalan kaki) $\mathrm{X}_{3}$. 


\section{DAFTAR PUSTAKA}

DLLAJ (2016). Perubahan Panjan (L, R, \& S)g Lintasan Trayek Angkutan Kota Bogor. Bogor (ID): DLLAJ

DLLAJ (2016). Perubahan Rute Trayek Angkutan Kota Bogor. Bogor (ID) : DLLAJ

DLLAJ (2016). Keputusan Walikota Bogor Nomor 551.45-63 Tahun 2016 tentang Tim Pelaksana Penerapan Sistem Satu Arah di Seputar Kebun Raya Bogor. Bogor (ID): DLLAJ

Kartika, L., Jayawinangun, \& Mangkuprawira. (2016). Manajemen Kompensasi. Bogor: IPB Press.

Kasikoen, K. M., \& Atmaja, S. S. (2012, Mei). Upaya Penanganan Permasalahan Lalu Lintas di Ruas Jalan Karet Raya Kecamatan Cibodas. Jurnal Planesa, 3(1), 1-4.

Mondy, R. W., \& Martocchio, J. J. (2008). Manajemen Sumber Daya Manusia. Jakarta, DKI Jakarta, Indonesia: Erlangga.

Purwanto, D., \& Priyono, E. E. (2015, Juli). Efektifitas Pemberlakuan Sistem Satu Arah pada Jalan Indraprasta Kota Semarang dalam Rangka Pemerataan Sebaran Beban Lalu Lintas. Media Komunikasi Teknik Sipil, 21(1), 47-55.

Putra, W. P. (2016, September 16). https://news.detik.com/berita/d-3300034/surveiwaze-bogor-jadi-tempat-terburuk-kedua-di-dunia-untuk-berkendara. Retrieved Maret 26, 2016, from https://news.detik.com: https://news.detik.com/berita/d3300034/survei-waze-bogor-jadi-tempat-terburuk-kedua-di-dunia-untukberkendara

Ramanasari, R., Qomariyah, N., Purwanto, D., \& Yulipriyono, E. E. (2014). Penerapan Manajemen Lalu Lintas Satu Arah pada Ruas Jalan SUltan AGungSisingamangaraja-Dr. Wahidin Kota Semarang untuk Pemerataan Sebaran Beban Lalu Lintas. Jurnal Karya Teknik Sipil, 3, 142-153.

Siregar, S. (2013). Metode Penelitian Kuantitatif. Jakarta, DKI Jakarta, Indonesia: Kencana.

Sugiyono. (2009). Metode Penelitian Kuantitatif, Kualitattif dan R\&D. Bandung, Jawa Barat, Indonesia: Alfabeta. 